\title{
The problematic and challenge of fiqh learning in school and madrasah in the covid-19 pandemic era
}

\author{
Firman Mansir \\ Faculty of Islamic Studies, Universitas Muhammadiyah Yogyakarta \\ Email: firmanmansir@umy.ac.id
}

\begin{abstract}
This research reveals that problematic and challenge occurred in fiqh learning in the covid-19 pandemic era are experienced by Islamic Education Institutions, especially madrasah. General education institutions, such as schools, experience the same thing. The two educational institutions face the same object in learning fiqh or Islamic religious education in public schools. In this Islamic education institution, the dominant subjects are those with religious elements. One of the subjects taught and as compulsory subjects in Islamic educational institutions is fiqh. Learning fiqh can come from the teaching staff, students, material, time allocation, material implementation, and infrastructure. Fiqh learning opportunities can be seen and adapted to the circumstances at the current time. The challenge of fiqh comes from many aspects, such as educators, students, and time allocation. With problems, challenges, and opportunities, fiqh learning will be more advanced following the times, especially in the covid-19 pandemic era.
\end{abstract}

Keywords: Fiqh Learning, School, Madrasah, Covid-19.

\section{INTRODUCTION}

In the Covid-19 pandemic era, Islamic education is needed to avoid amorality (Purnomo, H., Mansir, F., Tumin, T., Caswito, C., Gumiandari, S., \& Mualim, M, 2020). One of the Islamic religious studies that have become a concentration in Islamic Education Institutions is fiqh learning. 
Fiqh learning is taught from elementary to college level. Unfortunately, fiqh learning has many problems that must be resolved immediately so that fiqh learning can be implemented and applied in everyday life. The problems can come from educators, students, learning media, even from the facilities and infrastructure. Competent educators are those who can turn the problem into an advantage. If we look at Islamic educational institutions, actually learning fiqh also has opportunities. This opportunity can be utilized to support fiqh learning in madrasah and schools. A lesson taught in school can't just go on without challenges. Learning that does not have challenges means that it does not have power or strength in a school or madrasah, including fiqh learning.

Fiqh learning teaches Islam-based school or Madrasa starting from Madrasah Ibtidaiyah, Madrasah Tsanawiyah, and Madrasah Aliyah. Fiqh is a science containing Islamic law that is a charity based on the argument that has been interpreted by previous experts (Nurhayati, 2018). Fiqh learning is very important to be taught in schools and madrasah. With this knowledge, we can know the basics of a practice that we do. We can also know the commands and prohibitions that come from authentic or hasan hadiths that have been interpreted as true. As time went by, learning fiqh in schools or Madrasa often faces problems, opportunities, and challenges considered tests and twists and turns in teaching this fiqh learning.

Problematic is often called a problem. This problem is usually an obstacle to doing something. However, if this problem is managed properly, it can be an opportunity to use. For example, is the problem of 
learning fiqh in schools and madrasas. Many problems arise as the learning is carried out because fiqh science often requires practice in the implementation of learning. Thus, students can understand the essence of the material they understand. In this case, problems have started to emerge. Sometimes, educators find it difficult to find what kind of practice media is suitable to be applied to materials oriented towards things other than the world, for example, a description of other realms.

The challenge is often defined as a matter that needs a solution. Challenges can also be interpreted as something that can arouse the will to increase the ability to overcome a problem. Challenges often arise in various sectors of life, such as learning fiqh in schools and madrasas. Educators usually use this challenge as a strength that must be explored immediately to support progress in learning. This challenge often arises because of problems and opportunities. In solving a problem, the opportunity will be found, and it will usually provide clues to a challenge that must be resolved.

Problems, challenges, and opportunities can arise in various ways. This can arise from educators, students, the material being taught, the applicable curriculum, the facilities and infrastructure available, the school environment, and others. Suppose an educator is able to carry out the mandate well. In that case, he/she can solve existing problems, explore existing opportunities, and solve challenges that are found, and then the educator is considered to have competence. 
In the Dutch colonial era, Islamic education institutions had discrimination (Mansir, F., \& Purnomo, H. (2020). It caused the difficulty of accepting thoughts of things that never existed in Islam and pesantren. However, this precisely caused the Islamic community to be very enthusiastic about establishing Islamic education institutions. Over time, Islamic education institutions have currently received the same treatment and have become a sub of the National education system. This recognition was evidenced by the emergence of SKB (Joint Decree of Three Ministers), namely the Minister of Home Affairs, Minister of Religion, and Minister of Education and Culture in 1975 (Syukur, 2002). This recognition is not only part of the challenge but also an opportunity. It is because legally, the existence of an Islamic educational institution has been recognized. It becomes a challenge because, over time, national education will face problems regarding the minimum standards of education quality in the current era of globalization (Moh. Miftachul Choiri, 2011).

\section{METHODS}

The research method used is the literature study. The literature study method collects some data obtained through notes, works, or pictures. Thus, discussion or data obtained are the results of exploration from several relevant reading sources. This method can be implemented by first determining the topic to be discussed as the research problem. The data obtained are the result of exploration from books, journals, or related sources related to fiqh, schools and madrassa, fiqh problems in schools 
and madrasas, fiqh opportunities in schools and madrasas, and fiqh challenges in schools and madrasas. The technique used to analyze the data in this research is content analysis. The content analysis discusses content in reading.

\section{DISCUSSION}

Problematic is closely related to unsolved problems while learning problematic is problems in learning activities. Fiqh learning consists of knowledge about fiqh. The problems of learning fiqh occur when the learning process of fiqh takes place. Learning is modifying or reinforcing behavior through experience. This formulation implies that learning is a process, an activity, and not a result or goal. Learning is not just remembering, but broader and that, it is experiencing. Learning outcomes are not just mastery of exercises but changes in behavior. Learning is a process of changing individual behavior through interaction with the environment (A. Tabrani Rusyan, 1989).

Islamic education in Indonesia is not free from various problems, both acute and factual. Acute problems are problems such as debates between general science and religious sciences, factual problems such as problems in delivering education to students.

There are problems in revealing fiqh learning in Madrasa and schools, as follow: 
a. Aspect of teacher

The problem is the quality of teachers who can't encourage science transferring from teacher to student. In the learning process, the main subject is educators, and if the teacher is less competent, it will impact students (Mufris, 2014). Teachers are required to have broad insight and knowledge. Thus, learning can take place as it should. They are also required to have a good personality so that students can imitate them. However, at this time, many teachers are careless in transferring knowledge. They enter the class for just teaching, but they do not know whether they can be understood. Many students are also unable to apply fiqh learning according to what students expect.

b. Aspect of student

The success of learning can't be separated from the participation of students. The obstacles that often occur are the lack of focus of students while learning takes place. Students have different abilities. Thus, they have no effort to change themselves, or there is no effort to develop. When the learning process takes place, students should pay attention to the teacher carefully so that the teacher's material can be received well. There are still many students who ignore the teacher during learning.

c. Aspect of material

Materials that will be given to students consist of what needs to be given and what students must understand. Fiqh material is a 
definite material because it is Islamic law, and it requires a deeper understanding of Islamic law.

d. The aspect of time allocation

As fiqh learning needs better understanding, it is not enough if it is only studied quickly.

e. An aspect of Material Implementation

The material that has been taught will be more effective and efficient while accompanied by practice. Fiqh learning will be easier to understand if given an example or practiced directly during the learning process. For example, when the teacher explains the pilgrimage procedures, he/she, along with the students, practice the procedures for Hajj. This is considered effective because it eases students to digest the material given

f. Aspect of infrastructure

Infrastructure/facility for learning has a different meaning. Learning facilities are tools or media used when learning occurs in a room, for example, stationery in the classroom. Meanwhile, learning infrastructure is a tool or media that indirectly supports the learning process (Barnawi, 2012).

\section{The Opportunity of Figh in School and Madrasah}

Education is closely related to globalization. Indonesia will change the educational framework in the era of globalization by highlighting the development of a stronger and more flexible education system to enable 
graduates to work effectively in the life of a global democratic society (Karim, A., Mansir, F., \& Saparudin, T. (2020). Thus, education needs to be structured to cultivate their innate and creative abilities in an environment of independence, solidarity, and responsibility. Furthermore, education must produce students who can understand society with all the variables that can promote success or challenges that lead to social life failure. An alternative to this case is global education (Zamroni in (Hidayat, 2015).

In the current time, in which a very fast technological development marks the millennial era, information can be accessed very quickly, everyone can access any news. Yet, is this rapid development followed by an increased understanding of Islam? As far as studying in fiqh study is concerned, educators have usually tended to use lecture and question and answer methods so far. This situation is very likely to cause boredom because of the monotonous attitude shown by teachers who always talk constantly while the students listen quietly. This saturated state can result in an uncommunicative learning journey, which can cause difficulties in achieving learning goals.

In the case example, in implementing fiqh learning at MI Al Hasan, Sumpuih District, Banyumas Regency, it provides an understanding of lectures and questions and answers. It has also incorporated the content into action. Therefore, students who learn more understand practice (life skills) in fiqh content that is more about daily practice. Lifelong learning based on fiqh skills is learning that combines theoretical principles with 
experience. This is because fiqh skills instruction includes the ability to perform thaharah, mahdah worship, choice and consumption of halal food, and perform Islamic sharia-based muamalah practice with fellow humans, and protect the environment (Siswadi, 2016).

Other examples and cases: Learning Fiqh Thaharah at SDN Mundar, Lampihong, Balangan Regency, Mrs. Noor Hikmah, as a religion teacher, uses the demonstration method learning fiqh tharah. Students conduct more demonstrations or practice and lectures before practicing and selecting methods. This is because students have difficulty receiving the material if it is only conducted by the lecture method. Islamic Education teachers implement the expository and inquiry learning approaches at SDN Mundar in fiqh thaharah content. Thus, the findings obtained were comprehensive, including cognitive, affective, and psychomotor fields. Students are less concentrated if they are only given the type of lecture. We also need a diverse learning approach to be shared and accepted well by students (Ruwaida, 2019).

An Islamic Education teacher (PAI) can use some methods in fiqh learning below:

a) Lecture method

This method is learning to emphasize and give students a summary or clarification at a certain time (limited time) and a certain place.

b) Demonstration Method

Learning using demonstration is to explain a concept or to show how to do something for students. 


\section{c) Assignment Process}

This process is the way for teaching and learning, in which the instructor assigns a specific task, and the students work on it.

d) Drill approach

In the first view, this approach is the same as the examination. However, it is different. Testing is just about finding out how far the learning content is absorbed. In contrast, exercises are intended to enable students to have and fully master certain knowledge and skills.

e) Asking and answer approach.

This approach is usually used to cover shortcomings in the lecture system. Through this question and answer method, the instructor will know how students can understand the content presented. Meanwhile, it cannot be used as a definite measure to classically know student understanding because not every student has the same opportunity to answer questions.

\section{The Challenge of Fiqh in School and Madrasa}

Fiqh learning is currently considered to become subjects capable of playing an active role in motivating students to practice their religious values in daily life. Still, there are various challenges in implementing fiqh learning. Before discussing the challenges of fiqh in schools and madrasas, we need to describe the meaning of the challenges themselves. A challenge is a form of business that has the goal of arousing ability (Prayetno, 2015). Fiqh learning also has an important task for the life of every human being. 
Fiqh learning acts as positive law and moral standard. Positive law means that fiqh acts like any other positive law that governs daily life. Its role as positive law as well as fiqh places itself as moral or ethical. Thus, fiqh has a dual function or task, namely, positive law and morals (Hamidi, 2015). For this reason, fiqh must be taught from an early age to students. Thus, their lives are more focused. The challenges of learning fiqh include the imbalance between the material that must be taught and the time available (Mansir, F., Tumin, T., \& Purnomo, H, 2020). Religion-based learning in schools or madrasas often gets a portion of the time that does not match the material that must be taught.

School or Madrasa usually only give 2 hours in a week for fiqh subject in each class. It is simply not sufficient to achieve the desired goal. Sometimes the 2 hours are also wasted because of the needs of educators or other holidays. In fiqh learning, educators are required to teach the material and instill an understanding of students. Students' ability to absorb material is different from one another, and some are fast in capturing the material. Some require repeated explanations to be able to understand the material presented. In fiqh learning, there will always be debates because learning fiqh requires understanding. Thus, if the time available is not comparable with the material to be taught, students will be overwhelmed in understanding fiqh learning, especially fiqh material, which requires a deeper understanding of worship fiqh and others.

The next challenge is regarding the educators themselves. Educators in teaching fiqh material often use a monotonous method, namely the 
lecture method. This method is considered boring by students. Humans do something to obtain consequences in their daily lives, whether it's to meet needs or avoid punishment or unpleasant experiences. This also applies to educators (Mansir, 2018). Teachers consider students to have the same understanding as themselves to pursue learning targets, not instill understanding in students (Zahiroh, 2018). Teachers often compile achievement indicators in the syllabus only refer to the cognitive and psychomotor aspects, and the affective aspects are often overlooked. This can be seen in the daily lives of the students themselves, they know what the meaning of prayer is, how its movements are, but the wisdom of prayer has not yet been reflected in their daily lives.

The activeness of students also supports fun learning. If students are passive, this will be a challenge for teachers to make learning methods more creative and innovative. Thus, students will participate in fiqh learning with pleasure. Globalization is also a challenge for learning fiqh in schools and madrasas (Indra, 2016). The effect of globalization is on technological sophistication. The use of technology is increasing rapidly, especially for children who use it without parental supervision to impact their morale. This has become a new challenge for fiqh teachers to teach deeper morals so that this nation's generation will not become increasingly amoral in the future.

Madrasa and schools should face global developments and take responsibility for the Western cultural phenomenon (Mansir, F., Tumin, T., \& Purnomo, H, 2020). Globalization and the flow of knowledge have 
developed rapidly. It becomes a challenge, especially for students in madrasa institutions and Muslims, to not violate Islamic norms. Madrasa should be able to create outputs that truly preserve Islam to complete and noble Muslim youths. The first is as a means of actualizing the values of religious teachings. The second is as a preserver of religious practices within the framework of the Muslim community. The third is as a container and personality type for the younger Muslim generation, the fourth in as a bastion of national mobility that is now experiencing an unprecedented moral decline crisis. The approach in addressing the era of globalization is to expect something that includes Western culture with negative exposure to materialistic behavior and a way of life that seems free and not according to Islamic values (Abd Basid, 2019).

\section{CONCLUSION}

Islamic education in Indonesia can't be separated from acute and factual problems such as general science and theology. Madrasahs and schools' problems are often caused by internal factors, such as teachers, students, facilities, and infrastructure. This results in a lack of effectiveness in the learning process. However, the problems in Madrasahs and schools can be overcome by fixing the internals first. It can be started by the teacher who is required to provide material to students in an interesting way and use methods that are expected to be quickly absorbed by students. In line with the problems, to fix these existing problems is a challenge for all of us. Fiqh is a learning subject that is considered capable of playing an active 
role in encouraging students to be applied in their daily lives. Therefore, it takes sufficient time to convey this fiqh learning. Fiqh learning can be conveyed briefly, but it is feared that it will cause misunderstandings for students who absorb the material of fiqh directly without thinking about it first.

\section{REFERENCES}

A. Tabrani Rusyan, d. (1989). Pendekatan dalam Proses Belajar Mengajar. Bandung: jaRosdakarya.

Abd basid, M. I. (2019). Analisis Problematika Tantangan Madrasah

Sebagai Tipologi Lembaga Pendidikan Islam dan Solusi Dalam Mengahdapi Era Globalisasi. Ta'limuna, 21.

Barnawi, d. A. (2012). Manajemen Sarana dan Prasarana Sekolah. Yogyakarta: Ar-ruzz Media.

Hamidi, R. (2015). Epistemologi Islam: Telaah bidang Fiqih dan Ushul Fiqih. Jurnal Pengembangan Epistemologi Ilmu Hukum, 446.

Hidayat, N. (2015). Peran Dan tantangan Pendidikan Agama Islam Di Era Global. El-tarbawi, 140.

Indra, H. (2016). Pendidikan Islam Tantangan dan Peluang di Era Globalisasi. Yogyakarta: Deepublish.

Karim, A., Mansir, F., \& Saparudin, T. (2020). Managerial Leadership in Boarding and Public School: An Idea and Experience from Indonesia. Journal of Talent Development and Excellence, 12(2s), 4047 4059 . 
Mansir, F. (2018). Pendekatan Psikologi dalam Kajian Pendidikan Islam. Jurnal Psikologi Islam, 64.

Mansir, F., \& Purnomo, H. (2020). Islamic Education Learning Strategies Based on Multiple Intelligences in Islamic School. Psikis: Jurnal Psikologi Islami, 6(1), 48-57.

Mansir, F., Tumin, T., \& Purnomo, H. (2020). The Use of Active Learning Methods In Learning Fiqh Subjectat Islamic Boarding School. Lentera Pendidikan: Jurnal Ilmu Tarbiyah dan Keguruan, 23(1), 173-182.

Mansir, F., Tumin, T., \& Purnomo, H. (2020). Role Playing Learning Method in The Subject of Aqidah Akhlak at Madrasa. Nazhruna: Jurnal Pendidikan Islam, 3(2), 191-201.

Moh. Miftachul Choiri, A. F. (2011). Problematika Pendidikan Islam Sebagai Subsistem Pendidikan Nasional di Era Global. Problematika Pendidikan.

Mufris. (2014). Islamuna. Implementasi Pembelajaran Fiqh Mawarits di Madrasah Aliyah, 239.

Nurhayati. (2018). Figh dan Ushul Figh. Jakarta: Prenadamedia Group. Purnomo, H., Mansir, F., Tumin, T., Caswito, C., Gumiandari, S., \& Mualim, M. (2020). Tazkiyyat al-Nafs, Dhikr, and Sensitivity as Cultural Model of Indonesian Communities in Facing Covid-19 Pandemic. ibda: Jurnal Kajian Islam dan Budaya, 18(2), 228-243. 
Mudarrisa: Jurnal Kajian Pendidikan Islam, Vol. 12, No. 2, 2020

Prayetno, A. (2015). Kerjasama Komunitas ASEAN 2015 dalam Menghadapi Ancaman, Tantangan, Hambatan, dan Gangguan. Jurnal Ilmu Sosial dan Politik, 584.

Ruwaida, H. (2019). Strategi Pembelajaran Fiqih Thaharah di SDN Mundar Kecamatan Lampihong Kabupaten Balangan. Jurnal Pendidikan Madrasah Ibtidaiyah, 167-188.

Siswadi. (2016). Implementasi Pembelajaran Fiqih Berbasis Life Skill di MI Al Hasan Kecamatan Sumpiuh, Kabupaten Banyumas. 255-266.

Syukur, F. (2002). Madrasah di Indonesia: DInamika. Kontinuitas dan Problematika dalam Dinamika Pesantren dan Madrasah. Yogyakarta: pustaka pelajar.

Zahiroh, N. (2018). Tantangan Mengajar Pelajaran Fiqih Materi Khitan pada Jenjang Sekolah Dasar MI Thoriqotus Sa'adah Kabupaten Malang. Jurnal Pendidikan Agama Islam, 246. 